\title{
Critical discourse analysis of global warming public service advertisement: implication for students
}

\author{
${ }^{1} \mathrm{~A}$ 'thi Fauzani Wisudawati* and ${ }^{2}$ Novi Ika Setyani \\ 1,2 Universitas Sebelas Maret \\ Surakarta, Indonesia \\ *Corresponding author \\ Email: athiwisudawati27@gmail.com
}

\begin{abstract}
Preventing global warming through advertisement is considered as potential appeal. Since advertisement became one of material taught in the school, the importance not only affects the citizen but also influences how the teachers deliver the material by advertisement media. This study aimed at analyzing 4 non-profit public service advertisements and investigating how governments or advertisers use discourse and semiotics to encourage people to commit global warming avoidance. The four advertisements analyzed are global warming advertisements which have been selected from government's official website. The methodology adopted in this study is qualitative method. The advertisement is analyzed qualitatively in terms of content. Later on some English teachers have been interviewed to illustrate the implication of advertisement in pedagogical activities. This research finds that the teachers with their foresights can enlighten hidden values in public service advertisements.
\end{abstract}

Keywords: critical discourse analysis, Fairclough, advertisements, content analysis.

$\begin{array}{llll}\text { Received: } & \text { Revised: } & \text { Accepted: } & \text { Published: } \\ \text { 30 May 2018 } & \text { 26 July 2018 } & \text { 30 August 2018 } & \text { 31 August 2018 }\end{array}$

\section{INTRODUCTION}

The historical advertisements returns to $60 \mathrm{~s}$ and the point of notices was hard-offering with the assistance of some wise methodologies (Vahid \& Esmae'li, 2012), but nowadays, it turns towards a more commercial tool. According to Ruiz (2014), it is also an important genre, it is everywhere and it influences everyone. Again Ruiz (2014) defines advertising as a system inside promoting and it includes the trading of products and enterprises between individuals to fulfill their necessities. This indicates that advertising should make people happy by providing them to meet their needs. In terms of purposes of advertisements, it can be said that they are multi-functional because they can describe, warn, sell, inform, entertain and so forth. Still, the primary aim of advertisements is to persuade people to buy something or to accept an idea.

This study focuses on non-profit advertisement which aims to build awareness of the social problems and to motivate people to undertake socially desirable actions through the use of media. In figurative meaning, social 
Wisudawati \& Setyani, EduLite: Journal of English Education, Literature, and Culture Vol.3, No.2, August 2018, 149-160 DOI: http://dx.doi.org/10.30659/e.3.2.149-160

advertising hits both head and mainly heart. People should feel a responsibility to change their behavior. Social advertising has nothing to do with a product sale or with a service sale, as it is the case of commercial advertising that forces customers to buy something although they do not really need it.

According to Ministry of Education in Indonesia, advertisement text is a part of genre taught in Junior High School. The phenomenon of social advertising is also closely linked with the field of psychology and sociology. Psychology affects people's behavior and emotions. Emotions influence the way of the human minds which results in a change of people's behavior. There are many emotional appeals which need to be incorporated into the advertisements. Sociology deals with social life of individuals, groups or societies, and it is just social advertising that serves as means to get the message to a target group.

Nowadays, the topic of global warming has been arising due to its massive impacts. Global warming is often discussed as a broad impact in various parts of the world. The idea of global warming is characterized as an expansion in the temperature of earth's and sea's surfaces because of the increment in the measure of the ozone depleting substances in the air (Çimer, Sabiha, \& Ursavas, 2011). In Indonesia, global warming is one of the environmental problems being hotly discussed by several people lately, especially after the disaster of the smoke caused by forest fires in Sumatra and Kalimantan, Indonesia. Forest fires for months in Sumatra and Kalimantan significantly contribute as a greenhouse gas. In Indonesia, we can see that climate change and the season is not limited as a result of the impact of global warming. Other impacts which also have occurred in Indonesia are a change in the intensity and frequency of rainfall, crop system disorders, rising sea levels that causes flooding, increased rainfall and strong winds triggered landslides and land subsidence (Susanto \& Suyatna, 2015).

This part presents a related literature and theoretical background about discourse, critical discourse analysis. Since the framework of this study is based on a combination of several models such as Halliday, Fairclough, Kress and Van Leeuwen, this framework will be focused in detail below.

\section{Discourse analysis}

Several scholars revealed different definition in reference to discourse analysis. It is viewed as common methodology to report the analysis of text in context (Parker, 1992; Wodak, 1998; Wood \& Kroger, 2000). Discourse is considered to have higher system than sentences (Dohaei \& Ketabi, 2015; Stubb, 1983). Halliday (1994) discerned discourse analysis similar with structuralism's perspective. Two interpretations about discourse also stated by Schiffrin (1994) that belongs to part of language unit and language use focus.

\section{Critical Discourse Analysis}

Critical discourse analysis highlights the analysis of text. "Critical discourse analysis (often abbrieviated to CDA) provides theories and methods for the empirical study of the relations between discourse, social and cultural developments in different social domains" (Jorgensen \& Phillips, 2002). Critical Discourse Analysis (CDA) is a branch of discourse analysis that has 
particular point of view (Dohaei \& Ketabi, 2015). Van Dijk (as Cited in Bloor \& Bloor, 2007) defined CDA as a discipline of spoken and written analysis in the shade of humanity and social science field. In similar vein, CDA critically analyzes the language used by people who exercise power (Dohaei \& Ketabi, 2015). Wodak (2002) illustrated that language has a power whenever powerful person use of it. According to Fairclough (2003), 'SFL' is concerned with the relation between language and other aspects and elements of social life; therefore, it selects social character of a text and its approach to analyze texts linguistically as well.

Fairclough (1989) starts his critical studies by developing his theory of 'Critical Language Study' (CLS), which investigates the association between dialect use and unequal relations of power. He observed an increased consciousness of how language contributed to the domination of some people. His later works built up the techniques for CDA with the point of giving a way to deal with dialect examination open to those from disciplines outside phonetics with an accentuation on the connections between changes in dialect utilize and social and social component (Fairclough, 1992; 1995; Fairclough \& Wodak, 1997).

Fairclough (1989) provides us with a list of ten main questions and a number of sub-questions, which could be addressed when analyzing a text.

1. What experiential values do words have?

a. What classification schemes are drawn upon?

b. Are there words which are ideologically contested?

c. Is there rewording or overwording?

d. What ideologically significant meaning relations are there between words?

2. What relational values do words have?

a. Are there euphemistic expressions?

b. Are there markedly formal or informal words?

3. What expressive values do words have?

4. What metaphors are used?

5. What experiential values do grammatical features have?

a. What types of process and participants predominate?

b. Is agency unclear?

c. Are processes what they seem?

d. Are normalizations used?

e. Are sentences active or passive?

f. Are sentences positive or negative?

6. What relational values do grammatical features have?

a. What modes are used?

b. Are there important features of relational modality?

c. Are the pronouns we and you used and if so, how?

7. What expressive values do grammatical features have? Are there important features of expressive modality?

8. How are (simple) sentences linked together?

a. What logical connectors are used?

b. Are complex sentences characterized by coordination or/ subordination?

c. What means are used for referring inside and outside the text? 
Wisudawati \& Setyani, EduLite: Journal of English Education, Literature, and Culture Vol.3, No.2, August 2018, 149-160 DOI: http://dx.doi.org/10.30659/e.3.2.149-160

9. What interactional conventions are used? Are there ways in which one participant controls the turns of others?

10. What larger scale structures does the text have?"

Jorgensen \& Phillips (2002) highlight that critical discourse analysis beneficial to explore linguistic-discursive dimension of society and cultural phenomena and also processes of change in the social life. Moreover, CDA is interested in ways dialect and talk is utilized to accomplish social objectives and in part this utilization assumes a key part in social upkeep and change (Bloor \& Bloor, 2007).

\section{Advertising Discourse}

Woods (2006) and Bloor and Bloor (2007) emphasize that advertisements are complex and interdisciplinary although they are very short and scanty. Woods (2006) adds that there might be some informative advertisements while some other advertisements aim to persuade people. Tahmasbi and Kalkhajeh (2013) indicate that for ordinary people, it is hard to discriminate between informative and persuasive advertisements for which discursive patterns are very crucial in regard to creating the message. To find out the message, which is generally hidden, CDA could be a quite effective method.

When advertisement-related literature is examined, it is seen that intertextual elements are encountered in advertisements and most of the time; the genres that people generally follow take place purposefully (Williams 2003). This shows that advertisers really know the characteristics of their audience. By taking those characteristics into account, they are able to know how they should design their messages both visually and linguistically. At this point, it may be noted that the researchers who are conducting a CDA on advertisements should also give place to semiotics because signs are a form of communication. Another reason is that semiotic, as much as linguistic units, plays an important role in the connection between discourse and ideology. Accordingly, the focus of the present study is upon the critical analysis of discourse of non-profit advertisements by the government on the way of uncovering the implicit ideologies created with the power of words and images.

\section{METHOD}

\section{Research design}

A qualitative design was adopted for this study. A qualitative study was appropriate in this study which seeks to investigate how discourse in advertisements involves people's construction of meanings. The four advertisements were analyzed by using Fairclough's (1992) three dimensional framework. These dimensions are 1) description of textual analysis, 2) interpretation of production and reception, 3) explanation of social conditions which affect production and reception as seen in Figure 1 below: 


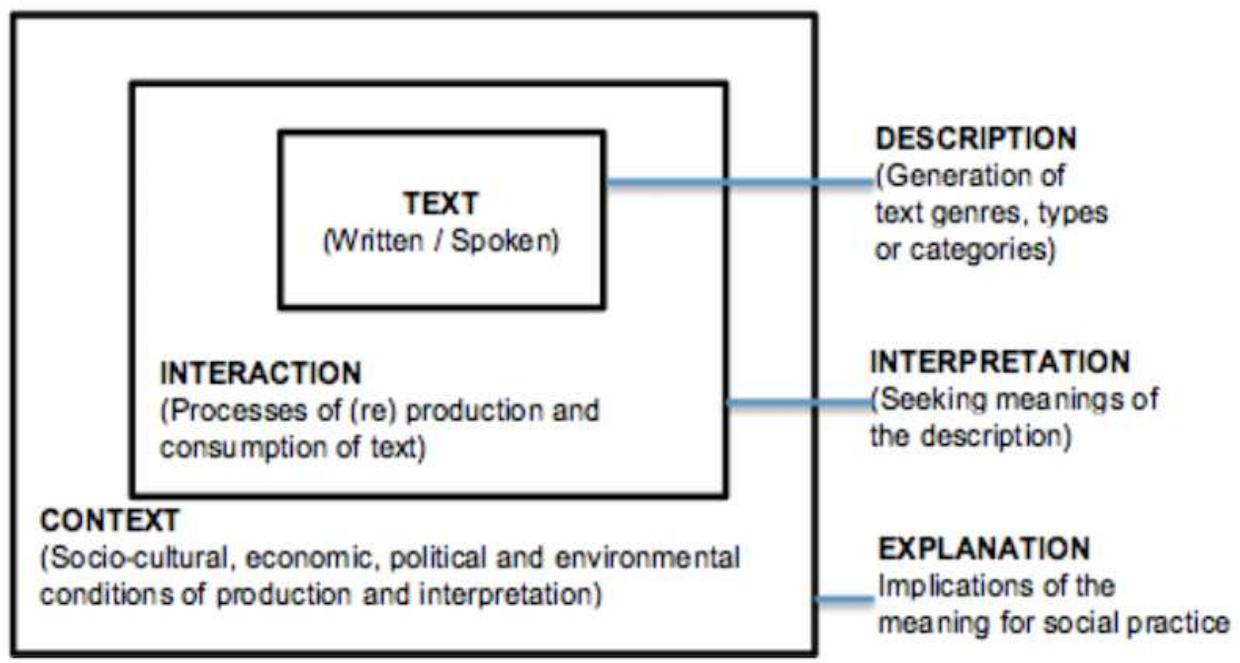

Figure 1. Three dimensional framework proposed by Fairclough (1992)

\section{Sampling}

4 non-profit advertisements under the theme "global warming" have been selected from the government's official website.

Table 1. Resources of advertisements

\begin{tabular}{llll}
\hline \multicolumn{1}{c}{ Resources of Ad 1 } & Resources of Ad 2 & Resources of Ad 3 & Resources of Ad 4 \\
$\begin{array}{l}\text { Official website of } \\
\begin{array}{l}\text { Singapore } \\
\text { Government: }\end{array}\end{array}$ & $\begin{array}{l}\text { Official website of } \\
\text { Singapore } \\
\text { Government: }\end{array}$ & $\begin{array}{l}\text { Official website of U.S } \\
\text { Government: }\end{array}$ & $\begin{array}{l}\text { Official website of } \\
\text { North Carolina } \\
\text { Government: }\end{array}$ \\
$\begin{array}{lll}\text { Ministry of the } \\
\begin{array}{l}\text { Environment and } \\
\text { water resources }\end{array}\end{array}$ & $\begin{array}{l}\text { Ministry of the } \\
\text { Environment and } \\
\text { water resources }\end{array}$ & $\begin{array}{l}\text { Atmospheric } \\
\text { Administration U.S } \\
\text { Department of } \\
\text { Commerce }\end{array}$ & $\begin{array}{l}\text { North Carolina } \\
\text { department of } \\
\text { environmental quality }\end{array}$ \\
\hline
\end{tabular}

An English teacher of Junior high school was also interviewed to relate the implications of the advertisements for the students.

\section{Data analysis}

Critical discourse analysis has been adopted to analyze the four advertisements. 
Wisudawati \& Setyani, EduLite: Journal of English Education, Literature, and Culture Vol.3, No.2, August 2018, 149-160 DOI: http://dx.doi.org/10.30659/e.3.2.149-160

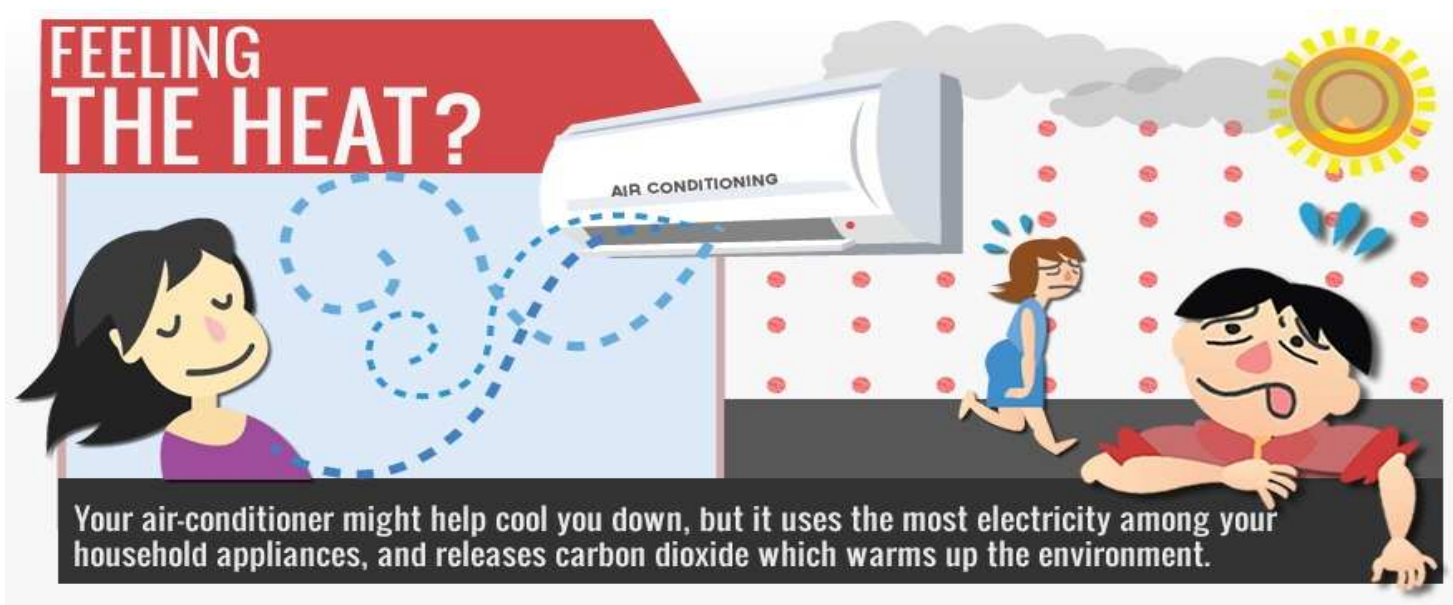

SHARE THIS INFOGRAPHICS WITH FAMILY AND FRIENDS! \&f SHARE 3 TWEet $<>>$ EMBED EMAlL

Figure 2. Official website of Singapore Government: Ministry of the Environment and water resources

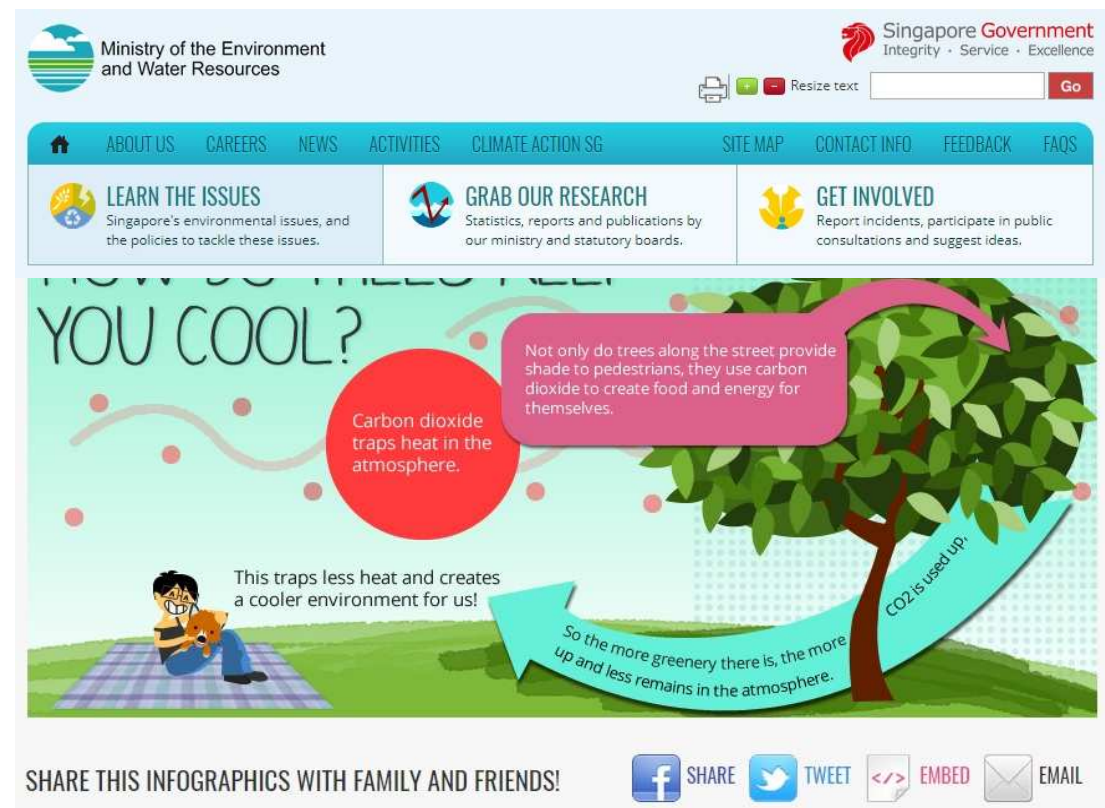

Figure 3. Official website of Singapore Government: Ministry of the Environment and water resources

National Ocean Service

National Oceanic and Atmmospheric Administration
U.S. Department of Commerce

HOME OCEANFACTS WHAT WEDO EDUCATION NEWS PODCASIS VIDEO IMAGES ABOUT US

What is place-based conservation? 
EduLite Journal of English Education, Literature, and Culture

Vol.3, No.2, August 2018, pp. 149-160

E-ISSN: 2528-4479, P-ISSN: 2477-5304

http://jurnal.unissula.ac.id/index.php/edulite DOI: http://dx.doi.org/10.30659/e.3.2.149-160

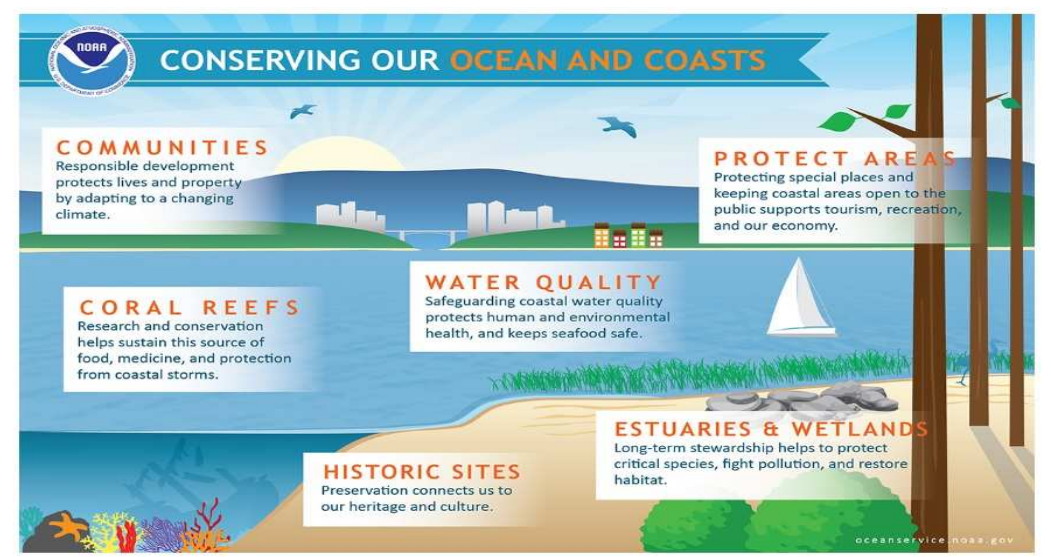

Figure 4. Official website of U.S Government: National Ocean and Atmospheric Administration U.S Department of Commerce

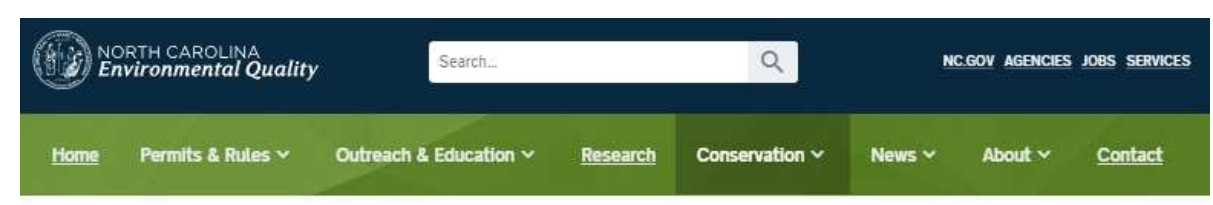

Home - Conservation - Recycling - Recycling Topics - Recycling and Climate Change

\section{Recycling and Climate Change}

Reducing waste, recycling and composting are effective ways to decrease the generation of greenhouse gases, such as carbon dioxide and methane. They achieve these benefits in two ways:

1. by helping save energy in the processing of materials for industrial and consumer use. and

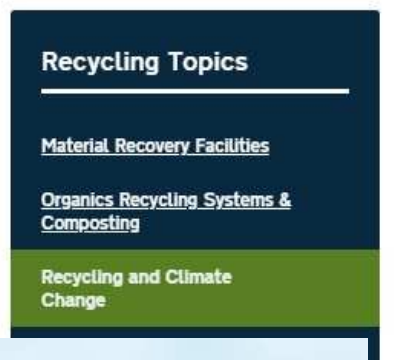

\section{RECYCLING SAVES ENERGY}

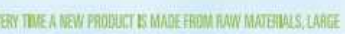

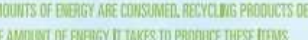
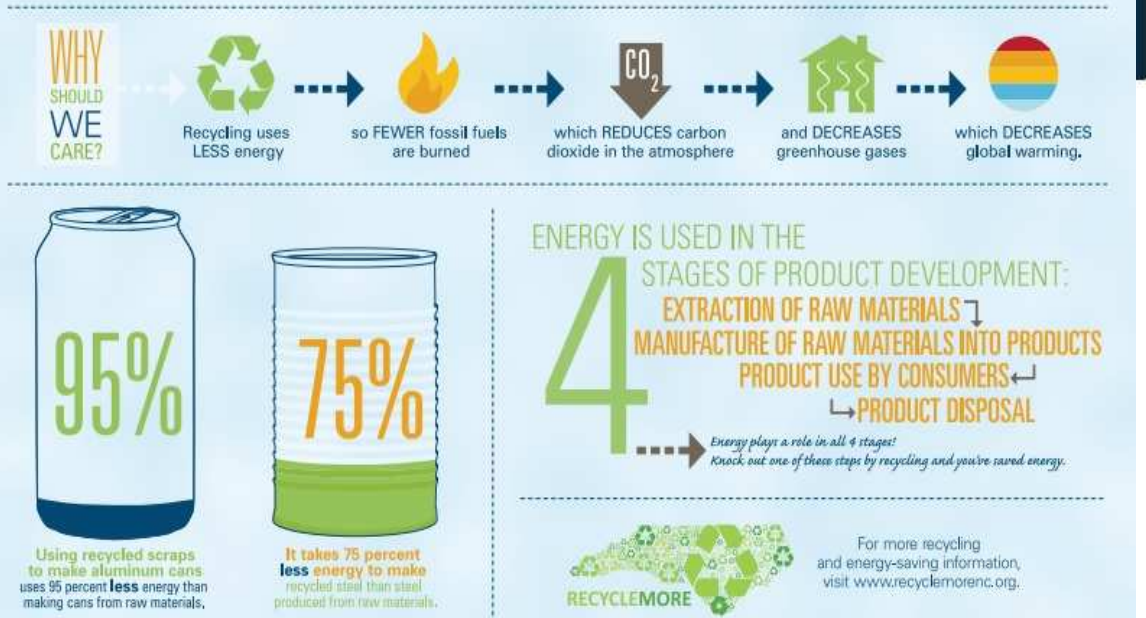

Figure 5. Official website of North Carolina Government: North Carolina department of environmental quality 
Wisudawati \& Setyani, EduLite: Journal of English Education, Literature, and Culture Vol.3, No.2, August 2018, 149-160 DOI: http://dx.doi.org/10.30659/e.3.2.149-160

\section{Analysis of advertisements}

\section{Dimension I: Description}

As Fairclough (1992) stated, the description dimension necessitates the analysis of both linguistic units and visual components of a text. Below is presented the Syntactic features in the advertisement

a) Use of simple sentences

To convey meaning clearly and simply, simple phrases are used to avoid vagueness or obscurity. Although they are phrases, they convey the meaning well, in a simple way.

b) Use of minor sentences

Using of minor sentences does not make the reader take time to read the advertisement; henceforth, he does not feel bored soon. It also leaves space for focusing on the picture.

c) Use of parallelism

The advertisement uses parallelism to add clarity, rhythm, and balance to the phrases uses.

In addition to linguistic units; images, background colors, visual display, and so on have been analyzed. Concerning images, it can be seen that the all the advertisements used apply certain images related to the environment. Below is the list of pictures used in the advertisements and the color of each item.

Table 2. The list of pictures used in the advertisements and the color of each item

\begin{tabular}{llll}
\hline \multicolumn{1}{c}{ Advertisement 1 } & Advertisement 2 & Advertisement 3 & Advertisement 4 \\
\hline Air: pink and blue & AC: white & Ocean: blue & Can: blue \\
Tree\& grass: green & Sun: orange & Grass: green & Barrel: green \\
Text Box: pink \& & Cool air: blue & Tree: brown & Text: orange, \\
red & Warm air: pink & Bird: blue & green, blue \\
Text: white \& black & Sweat: blue & Sea coral: colorful & \\
& CO2: grey & Land: cream & \\
& Text box: black \& & Ship: white & \\
& read & Sun: white & \\
& Text: white \& black & City: colorful & \\
& & Text box: white \& & \\
& & blue & \\
& & Text: blue, red \& & \\
& & white & \\
& & & \\
& & & \\
& & &
\end{tabular}

The color red is one thought to be the color which enflames emotions and feelings. It is a symbol of high energy. Red and its many shades of color are also used as a symbol of heart and love. Red has been found to have such a huge impact on people; it can even cause the heart to beat faster. It is an extremely powerful color. It is the bang that hits your eyes, and as a result, it symbolizes energy, power, vitality and vigor. Red is an attractive color to nearly everyone, and it can be used for anything exciting and able. Sometimes the power of products is described by the use of red.

The white color is used to write the letters to reflect safety and simplicity. The advertisement conveys a message by using white color in writing letters to show that this product is safe and simple. Colors are an integral part of our 
daily life. They are used in a special way in advertisements to attract customers; they convey deep meaning. Right colors please the eyes and send positive messages.

\section{Dimension II \& III: Interpretation \& Explanation}

The latter two stages of discourse analysis in Fairclough's three-dimensional framework are Interpretation, which concerns seeing text as both an outcome of production and a resource for interpretation, and Explanation, concerning the social determination of the processes of production and interpretation. Fairclough formulates four major questions in relation to the situation: 1) What is going on? 2) Who is involved? 3) In what relations? 4) What's the role of language? These questions correspond one to one with the four dimensions of a discourse type: Content, Subjects, Relations and Connections. After going through the four questions, the author will focus on the discursive level, and then explore the social determinants in broader terms.

a. What Is Going on?

In the first advertisement, it is shown that a man is holding his dog while lying down on the grass under a big tree, so that the fresh air surrounds him as well. Meanwhile, the second advertisement depicts an AC that produces the cold air indeed, however the electricity consumption brings the carbon dioxide production and this makes the environment warm and possibly leads to global warming. In the third advertisement, it can be seen that there are some healthy and clean environments in the ocean area. The last advertisement shows some steps in recycling saves energy in order to decrease global warming.

b. Who Is Involved? In What Relations?

Through these advertisements, the government tried to encourage the citizen to preserve the environment by avoiding some matters that may cause global warming. Global warming may come up because of our inappropriate treatment to the environment. By providing the public service ad, it enables to the government to have the environment preservation oration.

c. What Is the Role of Language?

Language in advertisement uses transactional language which prioritizes the content of communication. Language also can be conceived as interactional language which has the priority in interrelationship between addresser and addressee. In advertisement, language has a role to reflect the naturality of use value toward product commodity or service which are advertised. Here, language is also as a media to spread capitalistic consumerism ideology to society. The power of language which has brought the colonization of human cultural symbolic in advertisement, actually, to prove that the friction of language represents of one potency which can influence the existence of civilization at the present and the future 
Wisudawati \& Setyani, EduLite: Journal of English Education, Literature, and Culture Vol.3, No.2, August 2018, 149-160 DOI: http://dx.doi.org/10.30659/e.3.2.149-160

\section{RESULTS AND DISCUSSION}

English language teacher candidates' perceptions toward the advertisement were obtained through individual interviews. The results of the interview are presented as follows:

1. The use of advertisement text in secondary school

According to the interviewee, advertisement text is used as a teaching material for the second grade in junior high school. She explained that the advertisements used are mostly a profit advertisement. As said by her,

"The common advertisement text used in test paper is a profit ad. I have never found any of non-profit advertisement used to teach students."

The students are asked to draw their understanding upon the content and the purpose of the advertisement. Further, she described that students only focused on what is told by the questions. However, the advertisements found in many test papers are usually in black and white.

"But mostly they are in black and white. It declines the attractiveness of the advertisement itself."

2. Students' interest toward advertisement text

The English explained that students are relatively interested in learning advertisement text. This is due to the length of the text which is commonly short, so that they do not have to spend much of their time.

"Students are appealed to this kind of text because it is much easier to understand. Usually, the information is also quite clear that the students find it easy to understand."

3. The use of non-profit advertisement for students

It is stated by the English teacher that she once used a non-profit advertisement as teaching material. The students show their interest towards it.

"I once used an advertisement with PMI theme. They are interested in it and I think they learn not only about the information required, but also the explicit information from the advertisement."

It can be shown that students can obtain the message from the advertisement whether from the colour or from the picture used in the advertisement.

"I will absolutely happy if the government provides non-profit advertisements as teaching materials. Students will learn many things from them. They will get the message and maybe they can implement it in their daily life."

Based on the results above, it can be seen that the use of non-profit advertisement may bring many positive impacts for students. Students in junior high school are considered to be capable to get the explicit message from the advertisement. For example, from the blue colour, it is the colour of the sky and sea that often associated with depth and stability. It slows human metabolism and produces a calming effect. In addition, the use of cycle and simple diagram in mostly-found global warming advertisement will simplify the message carried by the advertisement itself to be understood by the students. 


\section{CONCLUSION}

Critical discourse analysis in reference to study of text and context analysis is beneficial in breaking down the significance of advertisement. Using Fairclough's theory, 4 non-profit advertisements under the theme global warming were analyzed through analysis based on critical discourse analysis study. Specifically those advertisements were utilized by the government as a means to courage the citizen to stay away from global warming. This thing can be categorized as an online media campaign to prevent and avoid nature disaster which unintentionally may caused by the human itself. However, the importance of advertisement also included in Indonesia's curriculum as one of material taught in junior and senior high school grade. Based on the observation and interview, commonly the teacher applied profit advertisements as the material in the classroom, non-profit ad such as global warming also potential to be a theme in conducting teaching and learning process.

\section{REFERENCES}

Bloor, T., \& Bloor, M. (2007). The practice of critical discourse analysis: An introduction. London: (p.2). Hodder education .

Çimer, Sabiha O., Çimer, A., \& Ursavas, N.. (2011) Student teacher's knowledges about global warming and changes their knowledges during pre-service education: A cross sectional study. Academic Journals, 6(8), 592-597.

Dohaei, M., \& Keetabi, S. (2015). A discourse analysis of coffee and chocolate print advertisements: Persian EFL learner's problem in focus. Mediteranian Journal of Social Sciences. Vol 6 No 3 . Doi: $10.5901 / \mathrm{mjss} .2015 . v 6 n 3 \mathrm{~s} 1 \mathrm{p} 220$

Esmae'li, S., \& Vahid, H. (2012). The Power behind Images: Advertisement Discourse in Focus. International Journal of Linguistics Vol 4, No 4. DOI: https://doi.org/10.5296/ijl.v4i4.2658 ISSN 1948-5425

Fairclough, N. (2003). Analyzing discourse: Textual analysis for social research. London and New York: Routledge.

Fairclough, N. (1989). Language and power. London: Longman.

Fairclough, N. (1992). Discourse and social change. Cambridge, UK: Polity

Jorgensen, M., \& Phillips, L. (2002). Discourse Analysis as Theory and Method. SAGE Publications.

Parker, I. (1992). Discourse dynamics: Critical analysis for social and individual psychology. London: Routledge.

Schiffrin, D. ( 1994). Approaches to Discourse. Oxford: Blackwell. Halliday, M. A. K. (1994). Introduction to functional grammar. (2nd eds.). Edward Armold (pub).

Stubbs, M. 1983). Discourse analysis. Oxford: Blackwell.

Susanto, B. \& Suyatna, A. (2015). Design learning media of global warming based on interactive multimedia with scientific approach to improve critical thinking skills. Proceedings of The 3rd South East Asia Development Reasearch Conference, 325-334. Palembang: Sriwijaya University. 
Wisudawati \& Setyani, EduLite: Journal of English Education, Literature, and Culture Vol.3, No.2, August 2018, 149-160 DOI: http://dx.doi.org/10.30659/e.3.2.149-160

Tahmasbi, S., \& Kalkhajeh, S., G. (2013). Critical discourse analysis: Iranian banks advertisements. Asian Economic and Financial Review, 2013, vol. 3 , issue $1,124-145$.

Wodak, R. (1998). Critical discourse analysis at the end of the 20th century. Research on Language and Social Interaction, 32, 185-194.

Wood, L. A., \& Kroger, R. O. (2000). Doing discourse analysis: Methods for studying action in talk and text. Thousand Oaks, CA: Sage 